\title{
Kesulitan Guru Sekolah Dasar dalam Mengembangkan Pembelajaran IPS Berorientasi Pendidikan Karakter Berbasis Kearifan Lokal
}

\author{
Frumensius B. Dole, Wahjoedi, I Nyoman S. Degeng \\ Universitas Negeri Malang \\ Universitas Flores
}

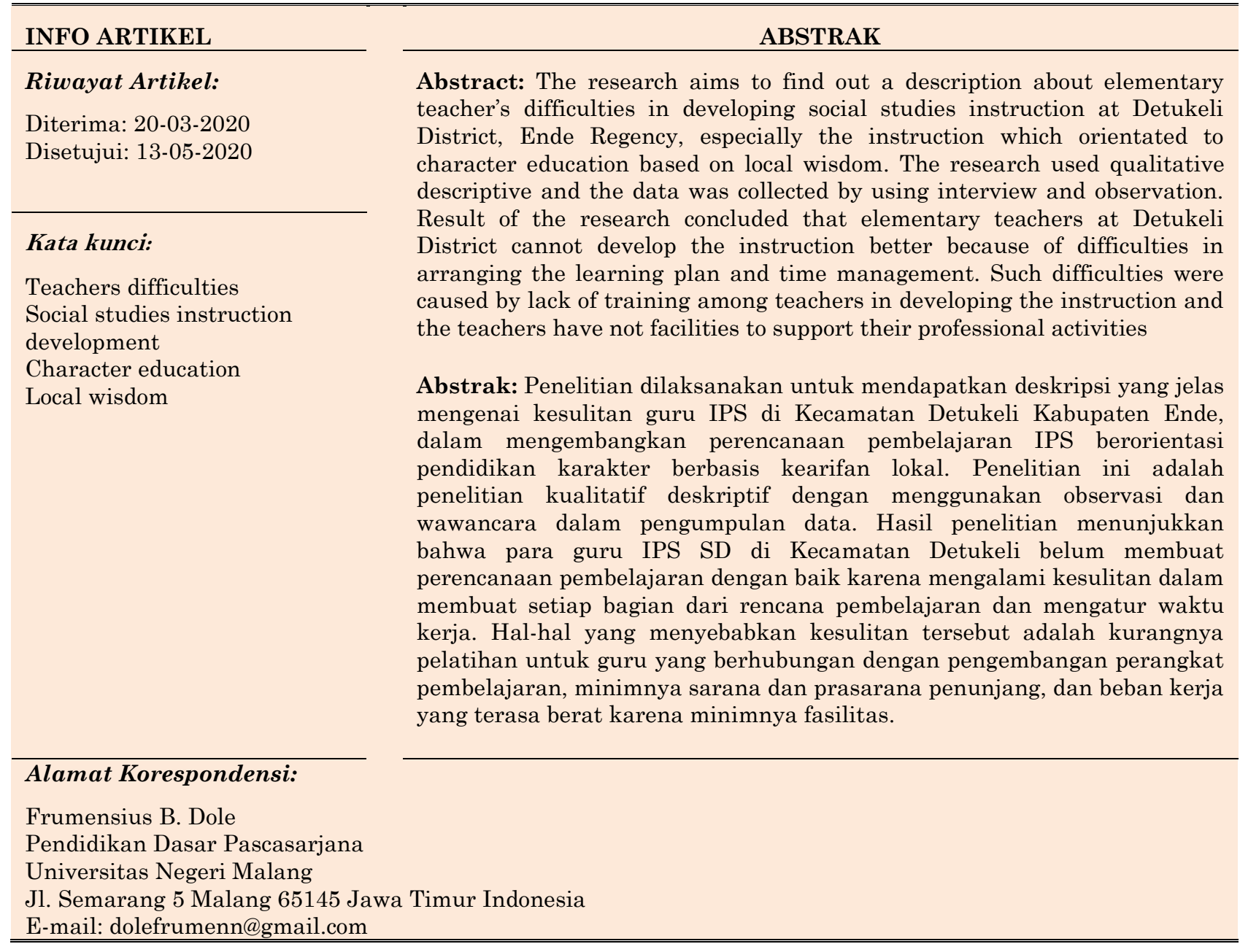

\section{PENDAHULUAN}

Non scholae sed vitae discimus, kita belajar bukan untuk sekolah melainkan untuk hidup. Kebenaran yang terkandung dalam kata-kata adagium Latin tersebut tentu saja bukanlah kebenaran teoretis yang menuntut pembuktian ilmiah, melainkan sebuah kebenaran asasi yang tak terbantahkan dan pembuktiannya melekat secara kodrati dalam realitas esensial hidup manusia. Manusia harus senantiasa belajar untuk hidup, dan setiap hal dalam hidup manusia adalah pelajaran yang diterimanya. Realitas ini menegaskan hubungan tidak terpisahkan antara hidup manusia dengan pendidikan yang juga adalah fundasi dari kesadaran manusia akan urgensi pendidikan (Haag \& Stern, 2000). 
Kesadaran tentang urgensi pendidikan secara umum sesungguhnya merupakan kesadaran akan nilai guna setiap pembelajaran. Dalam konteks pendidikan formal di sekolah, nilai guna pembelajaran adalah nilai yang mutlak harus dimiliki oleh setiap mata pelajaran dan menentukan layak atau tidaknya sebuah bidang dipelajari. Pendidikan IPS sebagai salah satu mata pelajaran di sekolah memiliki nilai guna sebagaimana tercermin dalam misinya yang sangat esensial dan strategis, yaitu membentuk, mengembangkan, dan melatih peserta didik menjadi warga masyarakat, bangsa, dan negara yang mempunyai pengetahuan, pemahaman, dan keterampilan yang komprehensif sehingga mampu menjalani kehidupan masyarakat modern dan tataran kehidupan masyarakat global (Mutiani, 2017).

(Banks \& Clegg, 1973)mengemukakan tujuan pendidikan IPS dikategorikan atas empat aspek yaitu pengetahuan, keterampilan, kepribadian dan nilai, serta kemasyarakatan, yang kesemuanya itu bermuara pada satu tujuan utama yaitu menyiapkan warga negara yang reflektif, mampu membuat keputusan secara tepat, serta dapat berpartisipasi secara baik dalam hidup bersama di lingkungannya, negara, dan dunia. Tujuan yang demikian dengan sendirinya menghadirkan tuntutan agar pembelajaran IPS di sekolah semestinya tidak dilaksanakan semata-mata untuk menyiapkan peserta didik melanjutkan pendidikan ke jenjang yang lebih tinggi, namun yang lebih penting adalah secara seimbang mengembangkan pengetahuan dan kepribadian peserta didik agar lebih baik dalam kehidupan bersama sebagai anggota masyarakat dan peka akan berbagai isu sosial (Budiarti, 2015).

Mencermati tujuan pembelajaran IPS dan dengan format ideal sebagaimana yang diuraikan di atas, dapat dilihat bahwa pembelajaran IPS semestinya memenuhi dua syarat hakiki yaitu: pertama kontekstual, di mana pembelajaran IPS dituntut untuk memiliki kontekstualitas yang utuh, baik dalam aspek material seperti materi pembelajaran serta alat dan bahan yang digunakan dalam pembelajaran, maupun juga dalam aspek sasaran atau tujuan pembelajaran. Dalam aspek material pembelajaran IPS semestinya memiliki konten yang terpadu dengan persoalan dan isu-isu sosial aktual yang ada dan berkembang di masyarakat. Dalam aspek tujuan, nilai-nilai yang hendak ditanamkan dan kemampuan-kemampuan yang diharapkan dimiliki oleh peserta didik dari sebuah pembelajaran IPS hendaknya ditentukan dengan memperhatikan kebutuhan peserta didik dan masyarakat. Kedua, memuat pendidikan karakter. Sehubungan dengan kontekstualitas tujuan pembelajarannya, sebuah pembelajaran IPS semestinya memiliki muatan pendidikan karakter. IPS sangat erat berkaitan dengan pendidikan karakter di mana keduanya memiliki tujuan membentuk peserta didik menjadi warga negara yang baik (Salam, 2017). Gross, sebagaimana dikutip (Darmadi, 2007), menegaskan bahwa values education as social studies "to prepare students to be wellfungtioning citizens in democratic society"

Pembelajaran IPS yang berkualitas dan memenuhi kedua syarat di atas adalah sebuah pembelajaran yang secara mutlak menuntut kinerja yang baik dari guru dalam pengembangannya. Baik dalam fase perencanaan maupun dalam fase pelaksanaan dan evaluasi, guru diharapkan melakukan tugasnya dengan baik, terpola, dan tepat sasaran sesuai tujuan pembelajaran yang ditetapkan. Guru dapat mengembangkan pembelajaran menjadi sebuah proses yang menyenangkan untuk dijalani siswa, dengan menggunakan semua instrumen secara kreatif dan unlimited sejauh relevan dengan pembelajaran, kondisi belajar dan keadaan peserta didik (Trinova, 2012).

Pemahaman yang benar tentang esensi pembelajaran IPS akan membawa kita pada pemahaman bahwa IPS tidak dapat dipisahkan dari pendidikan karakter, dan pendidikan karakter yang tepat dalam pembelajaran IPS adalah pendidikan karakter berbasis kearifan lokal. Pendidikan karakter berbasis kearifan lokal adalah upaya menanamkan keutamaan-keutamaan budi pekerti dan pola perilaku yang baik kepada peserta didik, dengan menggunakan cara pandang dan kebiasaan serta adat istiadat di lingkungan hidup peserta didik, termasuk di dalamnya nilai-nilai etika, moral, dan prinsip-prinsip keseimbangan hidup dalam relasi dengan sesama, lingkungan alam, dan dengan Tuhan (Priyatna, 2017).

Di Kecamatan Detukeli, pembelajaran IPS sebagian besar dilaksanakan dengan pola teks book oriented. Akibatnya, pembelajaran IPS menjadi "gersang" dan tercabut dari akar budaya masyarakat yang merupakan sumber dari pembelajaran IPS itu sendiri, apalagi buku pembelajaran yang digunakan adalah buku-buku karya penulis dari luar daerah dan tidak memuat konten lokal. Persoalan ini semakin kompleks, mengingat beberapa materi IPS pada jenjang sekolah dasar dapat terasa sedemikian abstrak bila guru tidak terampil memilih dan menggunakan media, atau menghadirkan contoh dari apa yang ada di lingkungan setempat. Hal ini tentu berpengaruh pada daya serap siswa, karena secara psikologis peserta didik khususnya pada jenjang sekolah dasar masih berada pada tahap operasional konkrit (Afandi, 2011). 
Pola pembelajaran IPS yang berorientasi pada buku teks, juga secara langsung akan berimplikasi pada minimnya atau bahkan tidak adanya tempat bagi kearifan lokal dalam pembelajaran. Dengan demikian, dapat dipastikan bahwa pendidikan karakter dalam pembelajaran itu menjadi tidak maksimal karena selain dibentuk dalam proses pendidikan di sekolah karakter identik dengan kepribadian atau akhlak seseorang yang bersumber dari bentukan-bentukan yang diterima dari lingkungan, misalnya keluarga pada masa kecil (Koesoema, 2007).

Penanganan atas persoalan pembelajaran IPS di sekolah-sekolah di Kecamatan Detukeli sebagaimana diuraikan di atas perlu dilaksanakan secara baik, terencana, berkesinambungan, dan dengan memperhatikan secara cermat faktor-faktor yang melatari persoalan tersebut. Untuk itu peneliti melakukan penelitian yang dikemas dengan judul "kesulitan guru SD dalam mengembangkan pembelajaran IPS berorientasi pendidikan karakter, berbasis kearifan lokal di Kecamatan Detukeli Kabupaten Ende (Salam, 2017). Penelitian ini bertujuan untuk mendapatkan deskripsi yang jelas mengenai kesulitan guru IPS di Kecamatan Detukeli, dalam mengembangkan silabus dan RPP IPS berkarakter, menggunakan kearifan lokal sebagai sumber belajar dalam pembelajaran IPS berkarakter, dan mengembangkan instrumen evaluasi pembelajaran IPS berkarakter (Priyatna, 2017).

Penelitian ini terfokus pada, pertama penyusunan perencanaan pembelajaran IPS berorientasi pendidikan karakter dengan basis kearifan lokal oleh guru (Dole, 2015). Dengan fokus penelitian ini, peneliti mengarahkan perhatian untuk mendapatkan deskripsi tentang penyusunan silabus dan RPP IPS berorientasi pendidikan karakter, dimulai dari perumusan indikator pencapaian kompetensi, pemilihan materi ajar dengan menggunaan kearifan lokal sebagai sumber belajar, perancangan skenario pembelajaran, dan pengembangan instrumen evaluasi pembelajaran oleh guru. Penyusunan silabus dan RPP dimaksud adalah penyusunan silabus dan RPP sesuai Kurikulum Tingkat Satuan Pendidikan (KTSP). Kedua kesulitan guru dalam membuat perencanaan pembelajaran IPS berorientasi pendidikan karakter dengan basis kearifan lokal. Setelah mendapatkan deskripsi tentang bagaimana pengembangan rencana pembelajaran untuk guru, peneliti ingin mendapatkan gambaran tentang kesulitan guru dalam membuat rencana pembelajaran (Kurikulum tingkat satuan pendidikan, 2007). Peneliti juga mengarahkan penelitian ini untuk menemukan faktor-faktor penyebab dari kesulitan-kesulitan guru tersebut agar masalah yang dialami guru dalam kegiatan pengembangan pembelajaran pada tahap perencanaan dapat dipahami secara menyeluruh dan mendalam (Alwi, 2017).

\section{METODE}

\section{Perencanaan Pembelajaran IPS Berorientasi Pendidikan Karakter Berbasis Kearifan Lokal di Kecamatan Detukeli}

Guru-guru IPS SD di Kecamatan Detukeli cenderung tidak membuat perencanaan pembelajaran, sehingga pembelajaran IPS yang berorientasi pendidikan karakter dan berbasis kearifan lokal boleh dikatakan tidak pernah direncanakan. Guru-guru mengakui bahwa nilai-nilai kearifan lokal dan karakter ditanamkan dalam pembelajaran secara spontan sesuai dengan materi yang diajarkan atau dengan situasisituasi kelas apa bila siswa mengalami situasi yang membutuhkan teguran, bimbingan, dan nasihat.

Guru-guru tahu bahwa di daerahnya terdapat kearifan lokal, dan mereka sering menggunakannya dalam pembelajaran, tetapi mereka tidak merencanakannya dalam perangkat pembelajaran. Diakui para guru, dalam hubungan dengan penanaman karakter peserta didik, internalisasi nilai memang dilakukan dengan menggunakan kearifan lokal. Nasihat-nasihat kepada siswa, ajaran tentang nilai-nilai pengorbanan, rela berkorban, dan berbagai nilai lainnya biasa mereka berikan dengan merujuk kebijaksanaan lokal, budaya dan adat istiadat, sera keteladanan tokoh seperti Ine Pare (Ibu Padi), dan pahlawan Marilonga. Namun dalam pembelajaran nilai-nilai ditanamkan tidak secara terencana, tertulis dan sistematis. Para guru kesulitan membuat perencanaan pembelajaran. Jika mereka membuatnya pun perangkat tersebut dipandang sebagai persiapan pengajaran pengetahuan semata. Penanamani nlai dilakukan secara spontan, sesuai dengan keadaan, bila guru merasa perlu memberikan nasihat atau wejangan.

Setelah mengetahui bahwa penanaman nilai-nilai dari kearifan lokal dalam pembelajaran IPS SD di Kecamatan Detukeli tidak direncanakan dengan membuat perangkat pembelajaran, peneliti berusaha mendalami masalah yang terjadi dalam pengembangan perencanaan pembelajaran, dan menemukan beberapa masalah yang dapat dideskripsikan sebagai berikut, 1. Guru tidak selalu membuat persiapan untuk 
setiap pertemuan, 2. Guru menggunakan Silabus dan RPP yang dikeluarkan oleh BSNP, 3. Guru menjadikan buku pelajaran yang ada sebagai patokan penyusunan rencana pembelajaran, 4. Guru hanya menggunakan media dan alat peraga konvensional seperti peta, globe, dan atlas. Guru tidak membuat alat peraga sendiri.

Perangkat pembelajaran berupa silabus dan RPP dikembangkan oleh guru dengan cara membuat penyesuaian atas silabus dan RPP yang dikeluarkan BSNP. Penyesuaian itu dibuat hanya dalam bentuk pengurangan indikator belajar disesuaikan dengan keadaan sekolah dan ketersediaan referensi, perubahan materi ajar, disesuaikan dengan ketersediaan buku referensi. Perubahan kegiatan pembelajaran atau langkah-langkah pembelajaran sesuai dengan keterampilan dan pemahaman guru tentang metode pembelajaran, juga dengan memperhatikan ketersediaan sarana, media, serta alat peraga. Perubahan instrumen evaluasi yang dibuat sendiri oleh guru sesuai dengan kisi-kisi yang direncanakan dan kemampuan guru membuat penilaian pada aspek kognitif, afektif, dan psikomotor. Dalam hal ini para guru cenderung melakukan penilaian hanya dalam aspek kognitif. Pengembangan RPP yang demikian pun tidak untuk setiap pertemuan.

\section{HASIL}

\section{Kesulitan Guru dalam Mengembangkan Rencana Pembelajaran IPS Berorientasi Pendidikan Karakter Berbasis Kearifan Lokal}

Guru mengalami kesulitan dalam mengembangkan rencana pembelajaran IPS yang berorientasi pendidikan karakter dan berbasis kearifan lokal. Kesulitan-kesulitan yang ditemukan sesungguhnya adalah juga kesulitan umum yang dihadapi guru dalam pengembangan rencana pembelajaran. Kesulitan guru mengembangkan perencanaan pembelajaran menyebabkan pembelajaran IPS yang berorientasi pendidikan karakter dengan basis kearifan lokal tidak direncanakan dengan baik. Kesulitan guru yang ditemukan dalam penelitian ini adalah guru tidak tahu bagaimana membuat perangkat pembelajaran. Guru sulit mengatur waktu untuk berbagai tugas, sementara mereka hanya bisa bekerja siang hari.

\section{Penyebab Kesulitan Guru}

Penyebab kesulitan guru yang ditemukan adalah jarang, bahkan tidak ada pelatihan, atau petunjuk tentang pengembangan perangkat pembelajaran untuk guru. Tidak tersedianya fasilitas dan sarana prasarana. Kalau pun ada, sangat minim/terbatas Penggunakan sistem guru kelas, seorang guru harus mengampu beberapa mata pelajaran. Tugas tambahan selain mengajar yang dibebankan kepada guru menyebabkan sering meninggalkan tempat kerja dan tugas mengajar.

\section{PEMIBAHASAN}

Pedoman Pengembangan Rencana Pelaksanaan Pembelajaran yang dikeluarkan (Depdiknas, 2006) telah memberi petunjuk tentang Langkah-langkah Pengembangan Rencana Pelaksanaan Pembelajaran (RPP), dimulai dari penulisan identitas sampai dengan perencanaan penilaian, lengkap dengan penjelasan tentang isi tiap-tiap komponen RPP. Pedoman tersebut dibuat dengan maksud untuk menjadi penuntun bagi guru dalam melakukan pengembangan rencana pembelajaran.

Pengembangan perangkat pembelajaran dengan langkah-langkah yang demikian tidak dilakukan oleh guru-guru IPS SD di Kecamatan Detukeli. Para guru memiliki perangkat pembelajaran yang dikopi, yang adalah contoh silabus dan RPP dari Badan Standar Nasional Pendidikan (BSNP). Beberapa silabus dan RPP yang dibuat guru dibuat dengan merubah contoh silabus dan RPP BSNP, dengan beberapa cara, seperti pengurangan indikator belajar disesuaikan dengan keadaan sekolah dan ketersediaan referensi, perubahan materi ajar, disesuaikan dengan ketersediaan buku referensi., perubahan kegiatan pembelajaran atau langkah-langkah pembelajaran sesuai dengan keterampilan dan pemahaman guru tentang metode pembelajaran, juga dengan memperhatikan ketersediaan sarana, media, serta alat peraga. Perubahan instrumen evaluasi yang dibuat sendiri oleh guru sesuai dengan kisi-kisi yang direncanakan dan kemampuan guru membuat penilaian pada aspek kognitif, afektif, dan psikomotor. Dalam hal ini para guru cenderung melakukan penilaian hanya dalam aspek kognitif (Wijayanti \& Sungkono, 2017).

Pengawas sekolah mengakui bahwa para guru di sekolah mengkopi perangkat pembelajaran BSNP, namun perangkat tersebut pun tidak digunakan dalam pembelajaran. pembelajaran dilakukan semata-mata 
dengan menggunakan buku teks, sedangkan perangkat pembelajaran hanya digunakan untuk kepentingan administrasi dan menghadapi supervisi. Kenyataan menunjukkan bahwa para guru sesungguhnya tidak mempersiapkan pembelajaran. Buku pelajaran menjadi satu-satunya pedoman guru dalam mengajar, sehingga guru sangat bergantung pada buku pelajaran yang dibeli dari beberapa penerbit atau diperoleh dari dinas pendidikan setempat. Apabila para guru melakukan pengembangan perangkat pembelajaran pun, itu dilakukan dengan berpatok pada buku yang mereka gunakan (Anugraheni, 2017).

Idealisme pembelajaran IPS yang berorientasi pendidikan karakter dengan basis kearifan lokal di Kecamatan Detukeli ternyata jauh panggang dari api. Perencanaan pembelajaran IPS yang berorientasi pendidikan karakter berbasis kearifan lokal, masih terkendala kesulitan-kesulitan mendasar seperti merumuskan tujuan pembelajaran dan indikator pencapaian kompetensi. Guru IPS SD di Kecamatan Detukeli masih belum dapat menyusun perencanaan pembelajaran dengan baik, termasuk merencanakan karakter yang hendak ditanamkan dan memasukan nilai-nilai kearifan lokal ke dalam materi dan kegiatan pembelajaran. Nilai-nilai karakter dan kearifan lokal belum direncanakan secara tertulis dan sistematis dalam perangkat pembelajaran (Priyatna, 2017).

\section{Kesulitan Guru SD di Kecamatan Detukeli dalam Mengembangkan Perencanaan Pembelajaran IPS Berorientasi Pendidikan Karakter Berbasis Kearifan Lokal}

Persiapan pembelajaran oleh guru IPS SD di Kecamatan Detukeli terhambat oleh beberapa kesulitan mendasar, yaitu guru belum tahu bagaimana mengembangkan perangkat pembelajaran dan sulit mengatur waktu untuk mengerjakan tugas pokoknya sebagai pengajar.

\section{Kesulitan Mengembangkan Perangkat Pembelajaran}

Guru-guru IPS SD di Kecamatan Detukeli mengaku belum memahami apa yang harus mereka lakukan dalam setiap langkah pengembangan silabus dan RPP, selain menuliskan kolom identitas pada bagian awal. Kesulitan ini sangat mendasar dan menjadi penyebab tidak berjalannya semua kegiatan perencanaan pembelajaran.

Keadaan di mana pengembangan perencanaan pembelajaran oleh guru terkendala kesulitan elementer yang bersifat teknis sungguh merupakan kenyataan yang memprihatinkan. Di saat Kurikulum Tingkat Satuan Pendidikan (KTSP) sudah berjalan delapan tahun, para guru masih bergelut dengan masalah teknis yang semestinya diatasi pada masa-masa awal pelaksanaan kurikulum. Kesulitan ini berkaitan langsung dengan kompetensi profesional guru. Namun kenyataan ini berbanding terbalik dengan kenyataan bahwa guru IPS SD di Kecamatan Detukeli pada saat penelitian ini dilakukan sebagian besar berkualifikasi pendidikan formal D3 dan S1 Pendidikan Guru Sekolah Dasar (PGSD), dan bahkan beberapa di antara mereka sudah mendapat sertifikat profesi dan menerima tunjangan sertifikasi. Hal ini menunjukkan bahwa kualifikasi pendidikan formal yang dimiliki guru di sana tidak menjadi jaminan dalam penguasaan kemampuan teknis pengembangan perangkat pembelajaran (Salamah \& Mufidah, 2019).

Fakta yang kontradiktif antara kualifikasi pendidikan formal dan kemampuan teknis pengembangan perangkat pembelajaran tersebut menurut peneliti dapat dijelaskan oleh sebuah fakta lain yaitu para guru di Kecamatan Detukeli pada saat penelitian ini dilakukan sebagian besar adalah guru senior yang sebelumnya adalah lulusan SPG, kemudian karena tuntutan kualifikasi pendidikan formal guru minimal S1 menempuh pendidikan lanjutan pada lembaga pendidikan belajar jarak jauh. Dengan kondisi di daerah yang serba terbatas, perkuliahan jarak jauh yang ditempuhnya tidak memberikan peningkatan kompetensi yang signifikan sebagaimana yang diharapkan (Nugroho, 2017).

\section{Kesulitan Mengatur Waktu Kerja}

Perencanaan pembelajaran semestinya dibuat untuk setiap pertemuan yang akan dilaksanakan. Dengan demikian, mempersiapkan pembelajaran adalah pekerjaan yang akan selalu dilakukan guru setiap hari dalam profesinya sebagai pengajar, selain melaksanakan pembelajaran dan membuat evaluasi. Demi mencapai tujuan pembelajaran sesuai apa yang telah digariskan dalam standar isi pembelajaran guru senantiasa berpikir tentang materi apa yang akan akan diajarkannya, bagaimana pembelajaran akan dilaksanakan, apa-apa saja yang harus disiapkan untuk pembelajaran, dan evaluasi yang bagaimana yang harus dibuat agar dapat mengetahui pencapaian dari pembelajaran yang akan dilakukannya (Hakim, 2009). 
Guru-guru IPS SD di Kecamatan Detukeli mengaku tidak dapat melakukan semua hal yang yang mesti dilakukan dalam mempersiapkan pembelajaran karena kesulitan mengatur waktu. Menurut para guru pekerjaan yang harus mereka lakukan terlalu banyak sedangkan waktu yang mereka miliki untuk bekerja sedikit. Hal ini tidak bermaksud mengatakan bahwa pekerjaan mereka lebih banyak dari guru-guru di tempat lain, tetapi pekerjaan mereka membutuhkan waktu yang lebih banyak dan kenyataannya waktu yang dapat mereka gunakan untuk bekerja tidak lebih banyak bahkan lebih sedikit dari waktu yang dapat digunakan guru di tempat lain (Anugraheni, 2017).

Kenyataan yang terjadi di Kecamatan Detukeli adalah para guru sepenuhnya bekerja secara manual. Untuk membuat sebuah tabel misyalnya, dibutuhkan waktu yang dua atau tiga kali lebih lama daripada dengan menggunakan komputer, karena guru harus menggaris dulu dan kemudian menuliskan isinya. Apabila terjadi kesalahan pekerjaan akan membutuhkan waktu lebih lama lagi karena harus menulis ulang semuanya. Hal ini semakin parah karena sepulang sekolah, di rumah para guru juga harus melakukan pekerjaan mereka dalam urusan rumah tangga.

Kesulitan yang dihadapi para guru ini selain karena pekerjaan yang dilakukan secara manual, juga disebabkan karena para guru di Kecamatan Detukeli hanya bisa secara efektif bekerja pada siang hari karena pada malam hari tidak ada penerangan yang memadai untuk bekerja. Dengan keadaan yang demikian, waktu kerja efektif para guru di Kecamatan Detukeli untuk menyiapkan pembelajaran praktis hanya siang hari sepulang sekolah hingga sore hari. Itu pun pekerjaannya tidak hanya menyiapkan pembelajaran, tetapi juga melanjutkan pekerjaan dari pembelajaran sebelumnya misalnya memeriksa pakerjaan siswa, membuat penilaian, dan ditambah berbagai aktivitas pribadi di luar tugas.

\section{Faktor-Faktor Penyebab Kesulitan Guru IPS SD di Kecamatan Detukeli dalam Mengembangkan Perencanaan Pembelajaran}

Kesulitan-kesulitan yang dihadapi guru IPS SD di Kecamatan Detukeli dalam mengembangkan perencanaan pembelajaran berdasarkan data penelitian ini berkaitan dengan beberapa hal yang diyakini menjadi penyebabnya. Hasil penelitian ini menunjukkan bahwa faktor-faktor penyebab kesulitan guru yang paling besar adalah kurangnya pemberdayaan dalam bentuk pendidikan dan pelatihan untuk peningkatan kompetensi guru, dan minimnya sarana prasarana baik yang berhubungan langsung dengan pekerjaan guru membuat persiapan pembelajaran maupun sarana infrastruktur wilayah.

\section{Penyebab Guru tidak Tahu Mengembangkan Perangkat Pembelajaran}

Kemampuan guru dalam membuat perangkat pembelajaran tentu hal yang sangat menentukan dalam upaya meningkatkan kualitas pembelajaran. Hasil dari sebuah proses pembelajaran yang kemudian secara akumulatif akan menjadi buah dari sebuah proses pendidikan bergantung pada bagaimana guru merencanakan pembelajaran. Oleh karena itu ketika guru tidak mengembangkan perencanaan pembelajaran dengan baik, sesungguhnya dunia pendidikan kita sedang mengalami sebuah masalah yang serius.

Pengakuan guru bahwa perencanaan pembelajaran tidak dapat mereka lakukan karena mereka tidak tahu apa yang harus dibuat dalam tiap langkah pengembangan silabus atau RPP menjadikan masalah yang dihadapi terasa sangat memprihatinkan. Betapa tidak, ketika para pengambil kebijakan sudah berpikir melakukan perubahan-perubahan kebijakan kurikulum, bahkan sampai pada gagasan untuk merubah kurikulum, pengetahuan teknis ternyata belum dimiliki oleh praktisi di lapangan. Menghadapi kenyataan yang demikian, tentu yang harus dilakukan adalah berusaha mengetahui penyebab persoalan karena hanya dengan demikian persoalan akan dapat ditangani dengan tepat. Pembahasan tentang penyebab kesulitan guru ini semata-mata adalah pembahasan atas dasar data penelitian ilmiah yang dilakukan dengan maksud melihat persoalan secara jernih, tanpa bermaksud melemparkan kesalahan kepada pihak tertentu atau menunjuk pihak yang harus bertanggung jawab atas masalah yang terjadi,

Ketidaktahuan guru tentang bagaimana membuat perangkat pembelajaran berdasarkan temuan penelitian disebabkan karena tidak adanya pelatihan atau bimbingan teknis yang diberikan kepada guru. Seorang guru mengatakan sebenarnya pernah ada pelatihan dengan tajuk pengembangan perangkat pembelajaran yang diikutinya, tapi yang terjadi dalam kegiatan tersebut bukan pemberian petunjuk teknis atau latihan melainkan hanya penjelasan umum tentang perangkat pembelajaran.

Persoalan ini sungguh merupakan hal yang memprihatinkan, mengingat Kurikulum Tingkat Satuan Pendidikan (KTSP) telah berjalan bertahun-tahun. Evaluasi terhadap isi kurikulum telah dilakukan, namun 
evaluasi tentang pelaksanaan kurikulum bahkan tidak mendeteksi persoalan dalam sosialisasi kurikulum. Bila permasalahan yang terjadi dihubungkan dengan kualifikasi pendidikan guru, stakeholder di daerah mungkin mengabaikan kemungkinan bahwa pelatihan teknis dibutuhkan oleh guru dalam sosialisasi pelaksanaan kurikulum karena secara formal para guru SD di Kecamatan Detukeli sudah banyak yang berkualifikasi pendidikan diploma dan sarjana. Namun ternyata fakta menunujukan hal yang berbeda. Kualifikasi pendidikan tersebut tidak berbanding lurus dengan kompetensi yang dimiliki guru.

Belajar dari persoalan yang terjadi, lembaga pendidikan tinggi yang menyelenggarakan pendidikan bagi calon pendidik dan tenaga kependidikan, baik yang berupa pendidikan jarak jauh maupun reguler, diharapkan secara sungguh-sungguh memperhatikan peningkatan kompetensi lulusan, agar kinerja lulusan ketika menjadi guru benar-benar sesuai dengan kualifikasi pendidikannya.

\section{Penyebab Kesulitan Guru Mengatur Waktu Kerja}

Perubahan paradigma tentang pekerjaan guru yang dulu sebagai pahlawan tanpa tanda jasa manjadi sebagai sebuah profesi menghadirkan tuntutan yang berbeda juga bagi yang menjalaninya. Dahulu, guru mengabdi semampunya tanpa standar beban kerja dan kewajiban-kewajiban profesional yang ketat. Sekarang, guru dituntut untuk melaksanakan kewajiban profesionalnya dengan ketentuan-ketentuan yang telah diatur dalam undang-undang guru dan dosen.

Standar beban tugas mengajar yang ditetapkan adalah 24 jam per minggu untuk guru, 12 jam per minggu untuk guru dengan tugas tambahan sebagai wakil kepala sekolah, 12 jam per minggu untuk guru dengan tugas tambahan sebagai pengelola perpustakaan, dan 8 jam per minggu untuk kepala sekolah (UU Guru dan Dosen). Apabila jam mengajar tidak memenuhi standar tersebut, guru dinilai belum memenuhi persyaratan sebagai guru profesional dan tidak mendapat tunjangan profesi. Di kecamatan Detukeli, standar beban tugas mengajar tersebut menjadi persoalan yang mempengaruhi kebijakan pembagian tugas guru. Dengan jumlah rombongan belajar yang hanya satu untuk setiap kelas, sekolah-sekolah paling banyak memiliki enam rombongan belajar, dan hanya kelas IV, V, dan VI yang melaksanakan pembelajaran dengan pemisahan mata pelajaran (non-terpadu), para guru terpaksa diberikan tugas sebagai guru kelas. Hal ini dikarenakan apabila pembagian tugas menggunakan sistem guru mata pelajaran, maka selain guru kelas I, II, dan III tidak ada yang dapat memenuhi standar 24 jam mengajar per minggu, apalagi di sekolah-sekolah yang hanya memiliki tiga rombongan belajar. Pembagian tugas sebagai guru kelas menyebabkan guru harus melaksanakan pembelajaran untuk lebih dari dua mata pelajaran setiap harinya.

Selain pembagian tugas sebagai guru kelas yang terpaksa dilakukan demi memenuhi standar jam mengajar minimal, beberapa guru juga mendapat tugas tambahan yang tidak diatur dalam undang-undang guru dan dosen, dan tugas tambahan yang di Kecamatan Detukeli paling terasa beban kerjanya adalah menjadi bendahara dana BOS. Kewajibannya untuk membelanjakan keperluan sekolah, membuat pembukuan keuangan, dan laporan pertanggunjawaban, berkonsultasi dengan staf dinas pendidikan kabupaten menyebabkan guru yang menjadi bendahara BOS sering bepergian ke kota dan meninggalkan tugas mengajar. Satu perjalanan pergi pulang ke ibukota kabupaten tidak dapat dilakukan dalam sehari karena angkutan umum hanya berangkat satu kali sehari. Ini berarti untuk satu keperluan di ibukota kabupaten, guru harus meninggalkan sekolah minimal dua hari.

Beban kerja sebagai guru kelas yang harus melaksanakan pembelajaran lebih dari dua mata pelajaran setiap harinya dan tugas tambahan sebagai bendahara dana BOS atau tugas tambahan lainnya menyulitkan guru apabila harus menyiapkan pembelajaran. Hal ini dikarenakan keadaan di Kecamatan Detukeli yang tidak memungkinkan guru bekerja hingga malam hari. Selain menggunakan waktu istrahat di sekolah, sepulang sekolah waktu yang dimiliki guru untuk bekerja efektif hanya sore hari. Pada malam hari tidak semua guru dapat bekerja dengan maksimal, dan tidak semua pekerjaan dapat dilakukan karena hampir semua guru di rumahnya hanya menggunakan penerangan seadanya seperti lantera dan pelita.

Keterbatasan sarana prasarana juga mempengaruhi beban kerja guru. Melakukan sebuah pekerjaan dengan fasilitas dan sarana yang cukup menyebabkan pekerjaan menjadi lebih mudah diselesaikan. Sebaliknya apabila sarana dan kelengkapan yang dibutuhkan tidak tersedia, pekerjaan akan terasa lebih sulit, memakan waktu yang lama, atau bahkan tidak dapat dikerjakan. Pekerjaan yang dapat dilakukan dalam waktu yang singkat dengan fasilitas dan perlengkapan yang memadai, dengan alat bantu kerja, akan membutuhkan waktu yang lebih lama bila tanpa fasilitas yang memadai dilakukan secara manuala. 


\section{SIMPULAN}

Kesimpulan yang dapat diambil dari hasil penelitian ini adalah bahwa pertama, realitas yang terjadi adalah para guru IPS SD di Kecamatan Detukeli hingga saat penelitian ini dilakukan belum melakukan perencanaan pembelajaran dengan semestinya termasuk merencanakan pembelajaran IPS yang berorientasi pendidikan karakter dan berbasis kearifan lokal. Penanaman karakter dalam pembelajaran IPS tidak direncanakan secara tertulis dan sistematis. Guru-guru menjadikan penanaman karakter sebagai sesuatu yang disisipkan secara spontan dalam pembelajaran apabila dirasa perlu, dalam bentuk nasihat atau wejangan bagi peserta didik. Demikian pun kearifan lokal, oleh guru digunakan dalam pembelajaran secara spontan sebagai contoh dan tidak direncanakan dalam perangkat pembelajaran. Kedua, tidak dibuatnya perencanaan pembelajaran oleh para guru IPS SD di Kecamatan Detukeli dikarenakan guru mengalami kesulitan membuat perangkat pembelajaran dan kesulitan mengatur waktu kerja. Ketiga, kesulitan-kesulitan guru di Kecamatan Detukeli disebabkan oleh beberapa hal yaitu (1) guru tidak diberikan pelatihan teknis tentang pengembangan perangkat pembelajaran; (2) minimnya sarana dan fasilitas penunjang; (3) penggunaan sistem guru kelas yang menyebabkan guru harus mengasuh beberapa mata pelajaran; (4) adanya tugas tambahan selain tugas mengajar, sehingga guru sering harus meninggalkan tugas pokok.

\section{DAFTAR RUJUKAN}

Afandi, R. (2011). Integrasi pendidikan karakter dalam pembelajaran IPS di sekolah dasar. Pedagogia: Jurnal Pendidikan, 1(1), 85-98.

Alwi, S. (2017). Problematika guru dalam pengembangan media pembelajaran. Itqan: Jurnal Ilmu-Ilmu Kependidikan, $8(2), 145-167$.

Anugraheni, I. (2017). Analisa faktor-faktor yang mempengaruhi proses belajar guru-guru sekolah dasar. Kelola: Jurnal Manajemen Pendidikan, 4(2), 205-212.

Banks, J. A., \& Clegg, A. A. (1973). Teaching strategies for the social studies: Inquiry, valuing, and decision-making Addison-Wesley Pub. Co.

Budiarti, Y. (2015). Pengembangan kemampuan kreativitas dalam pembelajaran IPS. Jurnal Pendidikan Ekonomi UM Metro, 3(1), 61-72.

Darmadi, H. (2007). Konsep dasar pendidikan moral. In Bandung: Alfabeta.

Depdiknas. (2006). Permendikas No. 22 tentang standar isi untuk satuan pendidikan dasar dan menengah.

Dole, F. B. (2015). Kesulitan guru SD di kecamatan detukeli kabupaten ende dalam mengembangkan pembelajaran IPS berorientasi pendidikan karakter berbasis kearifan lokal. In Program Pascasarjana UM.

Haag, L., \& Stern, E. (2000). Non scholae sed vitae discimus? Auf der Suche nach globalen und spezifischen Transfereffekten des Lateinunterrichts. Zeitschrift Für Pädagogische Psychologie/German Journal of Educational Psychology, 14(2), 146-157.

Hakim, L. (2009). Perencanaan pembelajaran. Wacana Prima.

Koesoema, D. (2007). Pendidikan karakter: Strategi mendidik anak di zaman global. Grasindo.

Kurikulum tingkat satuan pendidikan. (2007). Kurikulum tingkat satuan pendidikan.

Mutiani, M. (2017). IPS dan pendidikan lingkungan: urgensi pengembangan sikap kesadaran lingkungan peserta didik. Sosio-Didaktika: Social Science Education Journal, 4(1), 45-53.

Nugroho, P. J. (2017). Pengembangan model pelatihan inovatif untuk meningkatkan kompetensi guru SD daerah terpencil. Sekolah Dasar: Kajian Teori Dan Praktik Pendidikan, 26(2), 101-115.

Priyatna, M. (2017). Pendidikan karakter berbasis kearifan lokal. Edukasi Islami: Jurnal Pendidikan Islam, 5(10), 1-6.

Salam, R. (2017). Model Pembelajaran Inkuiri Sosial dalam Pembelajaran IPS. Harmony, 2(1), 7-12.

Salamah, U., \& Mufidah, N. (2019). Pengembangan profesionalisme guru melalui kualifikasi akademik dan kompetensi akademik. Proceeding International Conference on Islamic Education (ICIED), 4(1), 54-58.

Trinova, Z. (2012). Hakikat belajar dan bermain menyenangkan bagi peserta didik. Al-Ta Lim Journal, 19(3), $209-215$.

Wijayanti, S., \& Sungkono, J. (2017). Pengembangan perangkat pembelajaran mengacu model creative problem solving berbasis somatic, auditory, visualization, intellectually. Al-Jabar: Jurnal Pendidikan Matematika, 8(2), $101-110$. 